\title{
TRAUMATIC SHOCK. V. A STUDY OF THE EFFECT OF OXYGEN ON HEMORRHAGIC SHOCK
}

\author{
By HOWARD A. FRANK AND JACOB FINE \\ (From the Surgical Research Department of the Beth Israel Hospital and the Department of \\ Surgery, Harvard Medical School, Boston)
}

(Received for publication October 29, 1942)

The accumulating evidence from our studies of the plasma volume in hemorrhagic shock agrees with that of Gregersen (1) and of Evans (2), to the effect that there is no further loss of plasma from the circulation after the initial loss caused by the bleeding. Radioactive plasma proteins in the tissues of the dog in hemorrhagic shock are not found in greater concentration than in the unshocked dog. The irreversibility of hemorrhagic shock therefore cannot be explained by the theory of increased capillary permeability.

Venous anoxemia is one of the outspoken pathological phenomena in shock. It appears early, and the associated tissue anoxia, if prolonged sufficiently, might be considered responsible for the development of irreversibility because of irretrievable damage to vital structures. In that case, the prevention or amelioration of venous anoxemia might exert a beneficial therapeutic effect. Indeed, several recent reports $(3,4)$ claim such an effect from the administration of pure oxygen. The data given are not convincing, because the anoxemia was only partially corrected and the benefit derived consisted of temporary elevation of blood pressure or a prolongation of survival time by a few hours. A more definitive judgment as to the value of oxygen and the importance of venous anoxemia would require the prevention or complete correction of venous anoxemia. Only if a resulting change from the usual trend of events in shock is observed, can a therapeutic benefit from oxygen be claimed.

This communication presents experimental data showing that the usual trend of events in hemorrhagic shock is in no way influenced by oxygen so given as to prevent the occurrence of or restore to normal an already lowered venous oxygen.

\section{METHOD}

Since pure oxygen by tracheal cannula given to a dog in shock usually fails to restore the venous oxygen to a normal level, oxygen at more than one atmosphere was utilized with the expectation of better saturation, primarily because of increased oxygen in physical solution in the circulating plasma (5). Because four atmospheres of oxygen is lethal for dogs if carried on for the time intervals required for shock experiments, we performed all our experiments at three atmospheres of oxygen, in a pressure chamber made available to us by Dr. Drinker at the Harvard School of Public Health. Temperature and humidity were controlled throughout the experiment in the chamber and decompression carried out so as to avoid any ill effects from "the bends." Two control experiments were performed to observe possible deleterious effects of breathing three atmospheres of oxygen for a period of three hours-the maximum interval utilized in this study-in dogs prepared according to the technique described below, except that no blood was withdrawn. The dogs showed no effect on the blood pressure or in any other respect and recovery without incident ensued. .

Mongrel dogs were anesthetized according to Wiggers' technique (6), i.e., about one-half hour following an initial dose of morphine sulphate (3.0 mgm. per $\mathrm{kgm}$.) subcutaneously, sodium barbital (175 $\mathrm{mgm}$. per $\mathrm{kgm}$.) was given intravenously, two thirds of the dose in one injection and only as much more of the remaining third as was necessary for minimum anesthesia, sufficient to permit tracheal cannulation and exposure of vessels. No further anesthetic was required, although the lid reflex was present and many dogs were on the verge of recovering consciousness in the later stages. Blood was withdrawn fractionally from the femoral artery over a period of one-half to $1 \frac{1}{2}$ hours, until the arterial blood pressure fell to $70 \mathrm{~mm}$. $\mathrm{Hg}$ and did not rise within fifteen minutes after the last withdrawal. No further blood, except for sampling, was removed, regardless of any subsequent recovery of blood pressure. In all, some 30 to 40 per cent of the estimated total blood volume was withdrawn. Plasma volumes before and after bleeding were measured by the method of Gibson and Evelyn (7). Hematocrits were determined in Wintrobe tubes containing heparin or oxalate. The plasma proteins were determined by the falling drop method, using heparin as an anticoagulant. All specimens for plasma volume, hematocrit, and plasma protein determinations were taken from the femoral artery. The blood pressure was measured at intervals in a mercury manometer by needle puncture of the femoral artery. Tests of reversibility by intravenous fluids, blood; or plasma were occasionally performed. Venous blood was taken from the right heart through a glass tube inserted into the left external jugular 
vein. Samples for blood gas measurement were collected under oil, using crystalline oxalate as an anticoagulant, and analyzed by the manometric method of Van Slyke and Neill (8). Oxygen, in excess of hemoglobin saturation, dissolved in plasma at elevated pressures, presumably escaped before analysis at atmospheric pressure. Plasma pH determinations were made by the colorimetric method of Hastings and Sendroy (9). Oxygen was inhaled from a calibrated spirometer via a tracheal cannula. Expiration led out to the room air, except when oxygen consumption was measured, in which case it was returned through soda-lime to the spirometer.

\section{RESULTS}

The data are presented in two groups: $(I)$ experiments in which the oxygen was given after the dog was in shock, and $(I I)$ experiments in which the oxygen was started before blood was withdrawn or before shock from hemorrhage occurred.

Group I. Oxygen at three atmospheres, given after shock was established. Five dogs were bled to a shock level of blood pressure $(70 \mathrm{~mm} . \mathrm{Hg}$ ) and were allowed to remain in shock $11 / 2$ to $21 / 2$ hours. Oxygen at three atmospheres was then supplied for $11 / 2$ hours or longer. In two dogs, the venous oxygen concentration was only partially restored (Figure 1 ). In the remaining three animals, the venous oxygen concentration returned to its original normal level or to a level above normal (Figure 2). Nevertheless, all five dogs exhibited a progressive decline in blood pressure terminating in death. The average survival time was about four hours following the termination of the bleeding. Only one dog showed a partial recovery of blood pressure, but death followed rapidly after decompression.

In three of the dogs in terminal collapse after decompression, the rapid intravenous injection of a volume of saline, exceeding that of the blood withdrawn, resulted in an increase in the venous blood oxygen, but collapse and death followed shortly thereafter. The rise in venous oxygen in one instance (Figure 3) greatly exceeded that effected by oxygen inhalation. In a second instance, the already normal venous oxygen was

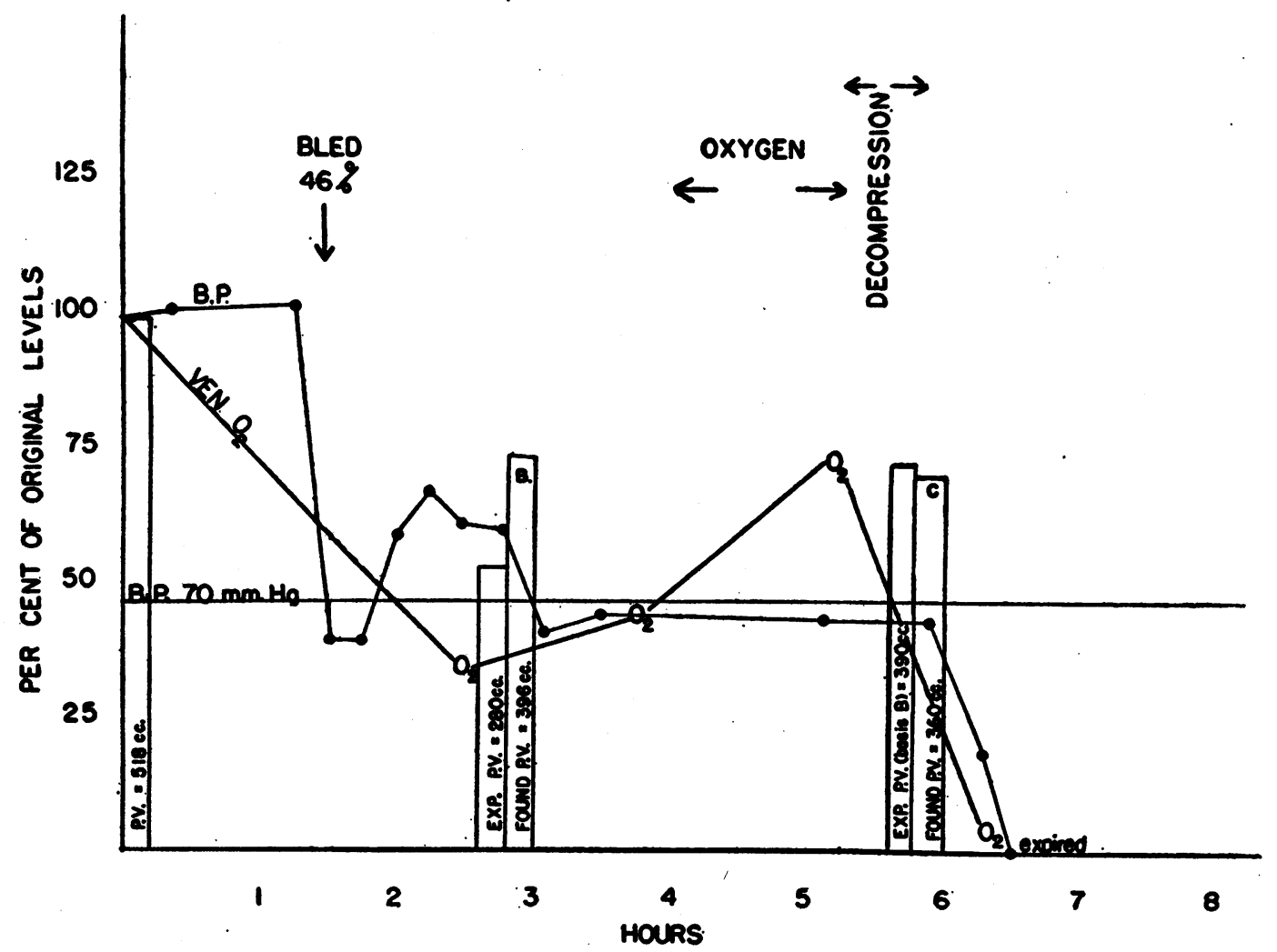

FIG. 1. (Exp. 2.) Slight mobilization of plasma after bleeding. No further loss during shock state. Oxygen inhalation corrected anoxemia without influencing blood pressure or prolonging life. 


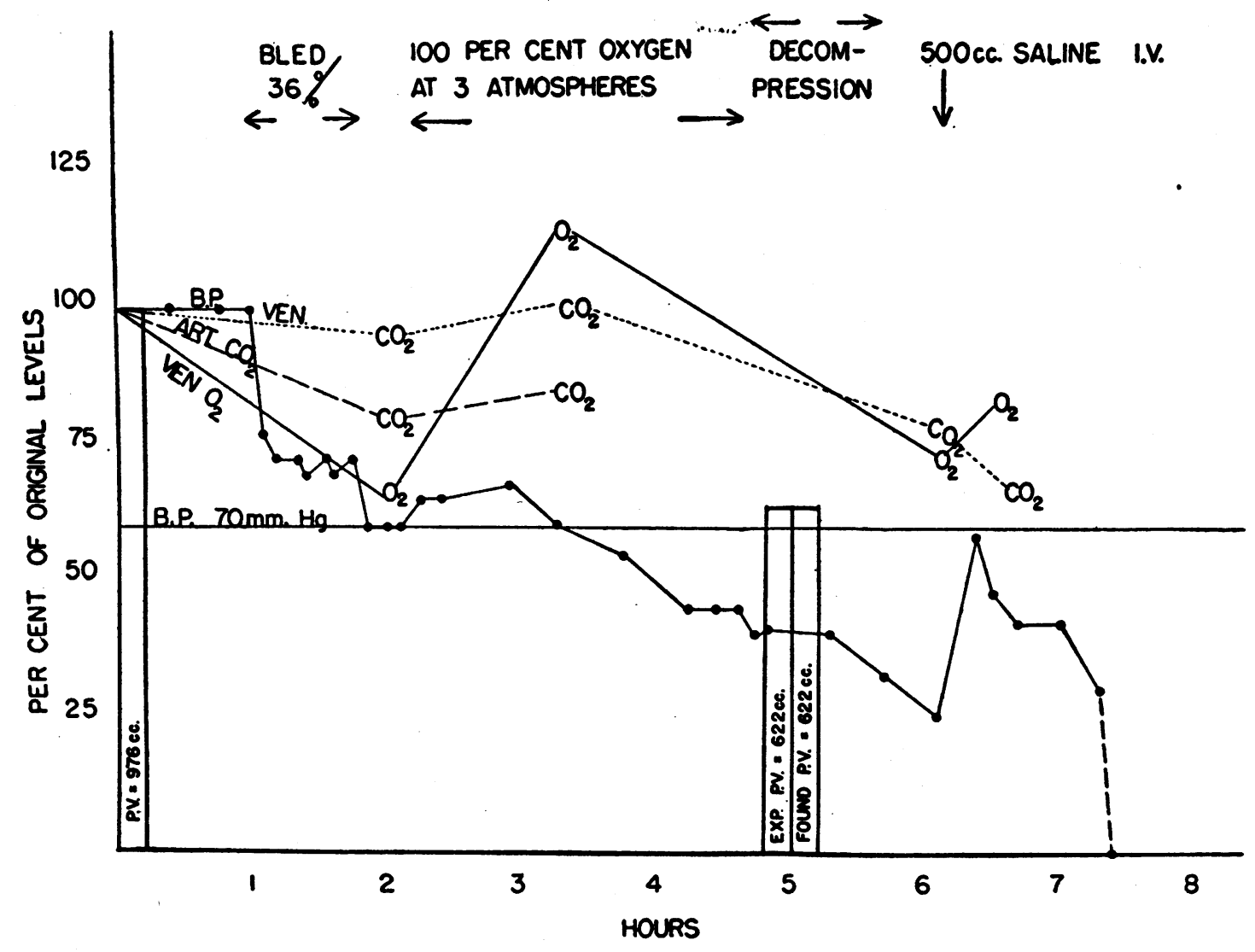

Fic. 2. (Exp. 11.) No plasma loss from capillary leakage. Anoxemia corrected but no effect on blood pressure or survival time.

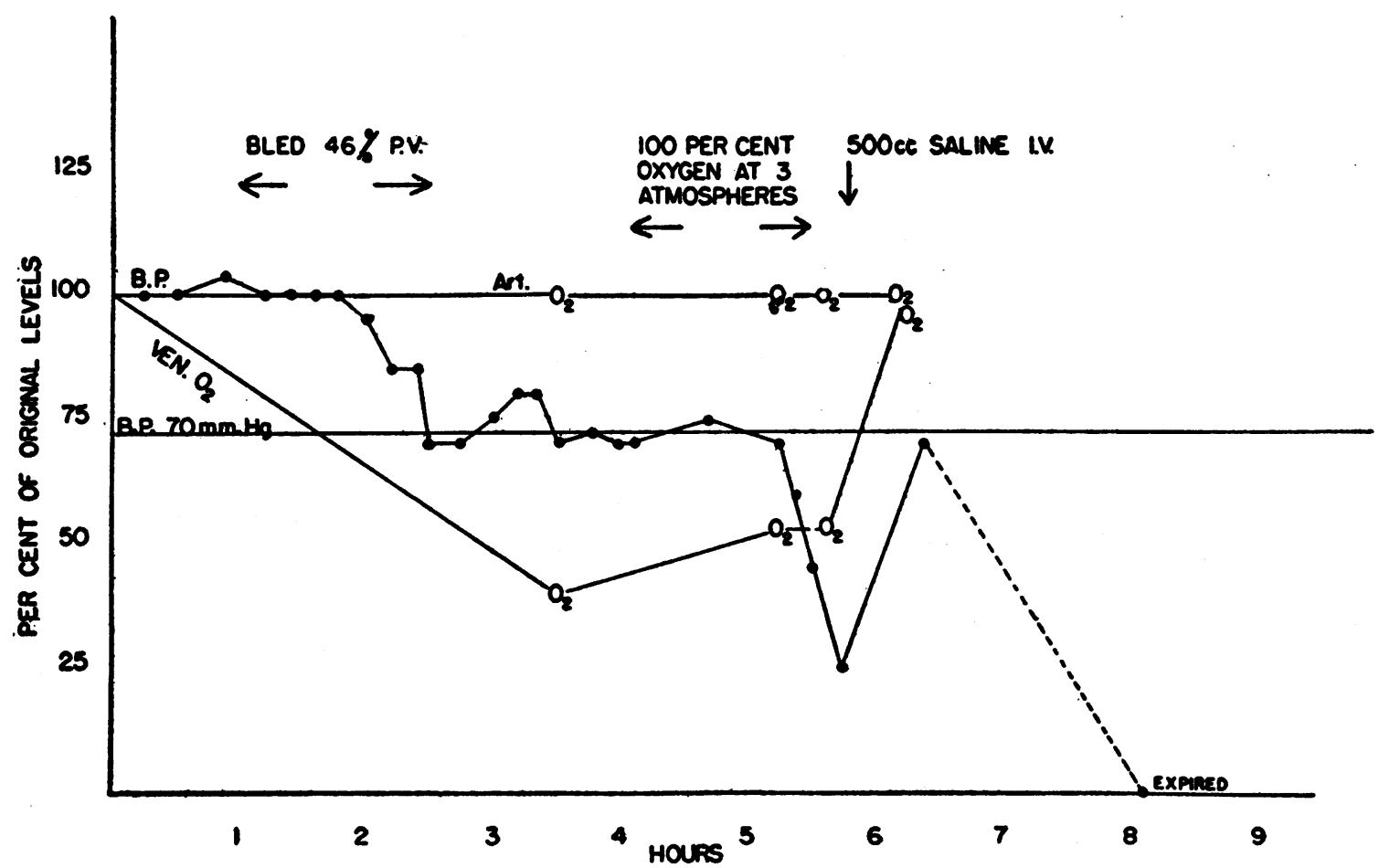

FIG. 3. (Exp. 4.) Inhalation of oxygen partially improved venous anoxemia but saline solution restored it to normal. Blood pressure and survival time not affected by oxygen. 
TABLE I

Arterial and venous blood oxygen content before and during shock, and before and during the inhalation of oxygen at 3 atmospheres

\begin{tabular}{|c|c|c|c|c|c|c|c|c|}
\hline \multicolumn{4}{|c|}{ Control period } & \multicolumn{4}{|c|}{ Shock period } & \multirow{3}{*}{$\begin{array}{l}\text { Survival } \\
\text { following } \\
\text { onset shock }\end{array}$} \\
\hline \multirow{2}{*}{$\begin{array}{l}\text { Experiment } \\
\text { number }\end{array}$} & \multirow{2}{*}{$\begin{array}{c}\text { Arterial } \\
\mathrm{O}_{2}\end{array}$} & \multirow{2}{*}{$\begin{array}{c}\text { Venous } \\
\mathrm{O}_{2}\end{array}$} & \multirow{2}{*}{$\begin{array}{c}\text { Blood } \\
\text { volume } \\
\text { withdrawn }\end{array}$} & \multicolumn{2}{|c|}{$\begin{array}{l}\text { Breathing } \\
\text { room air }\end{array}$} & \multicolumn{2}{|c|}{$\begin{array}{l}\text { Breathing oxygen } \\
\text { at } 3 \text { atmospheres }\end{array}$} & \\
\hline & & & & $\begin{array}{c}\text { Arterial } \\
\mathrm{O}_{2}\end{array}$ & $\begin{array}{c}\text { Venous } \\
\mathrm{O}_{2}\end{array}$ & $\begin{array}{c}\text { Arterial } \\
\mathrm{O}_{2}\end{array}$ & $\begin{array}{l}\text { Venous } \\
\mathbf{O}_{2}\end{array}$ & \\
\hline $\begin{array}{r}4 \\
2 \\
11 \\
5 \\
6\end{array}$ & $\begin{array}{l}\text { volus } \\
19.0 \\
18.9 \\
17.8 \\
22.8\end{array}$ & $\begin{array}{r}\text { cent } \\
15.0 \\
17.6 \\
13.4 \\
14.8 \\
16.7\end{array}$ & $\begin{array}{c}\text { per cent } \\
46 \\
46 \\
36 \\
63 \\
60\end{array}$ & $\begin{array}{l}\text { volun } \\
19.1 \\
19.3 \\
18.9 \\
23.1\end{array}$ & $\begin{array}{r}\text { cent } \\
5.9 \\
6.6 \\
8.7 \\
8.3 \\
10.3\end{array}$ & 19.0 & $\begin{array}{r}\text { cent } \\
8.1 \\
13.4 \\
15.4 \\
15.0 \\
16.8\end{array}$ & $\begin{array}{c}\text { hours } \\
3 \frac{1}{2} \\
5 \\
4 \frac{1}{2} \\
3 \frac{1}{2} \\
4 \frac{1}{2}\end{array}$ \\
\hline
\end{tabular}

increased, and in a third, a rapidly falling venous oxygen level was increased only slightly. The effect of intravenous fluids on the venous oxygen was regarded as a result of the temporarily increased velocity of flow.

A period of $11 / 2$ to three hours of inhalation of oxygen at three atmospheres therefore did not modify the course of events in shock from hemor- rhage, whether the venous oxygen was or was not restored to normal (Table I).

Group II. Oxygen at three atmospheres given prior to bleeding and continued during shock. In an attempt to eliminate any period of anoxemia which might cause injury not amenable to subsequent oxygen therapy, five dogs were bled in the same manner as those in Group I, but after

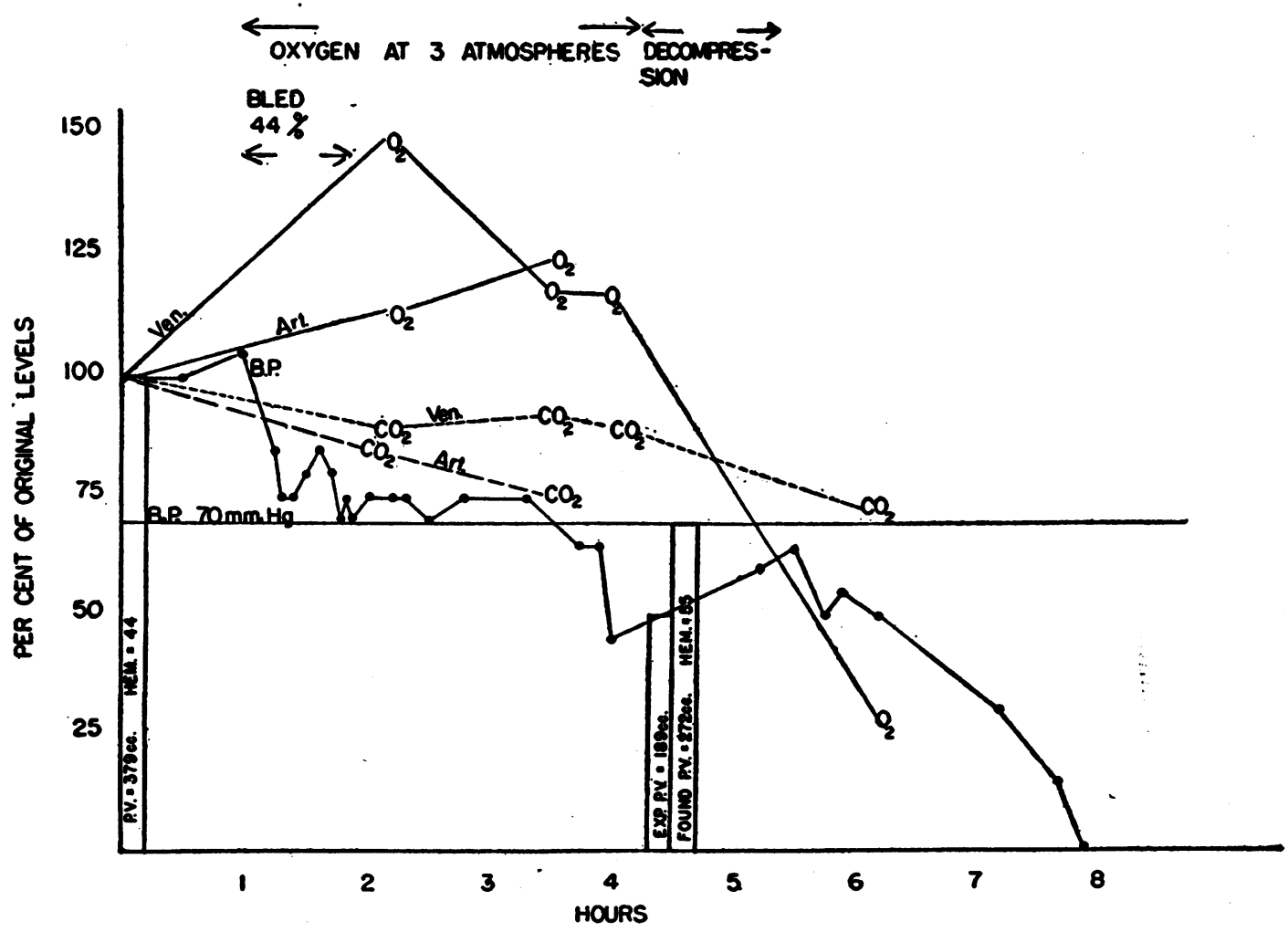

Fig. 4. (Exp. 15.) Plasma volume not lost into tissues during shock. Anoxemia prevented by oxygen inhalation but survival time and blood pressure not affected. 


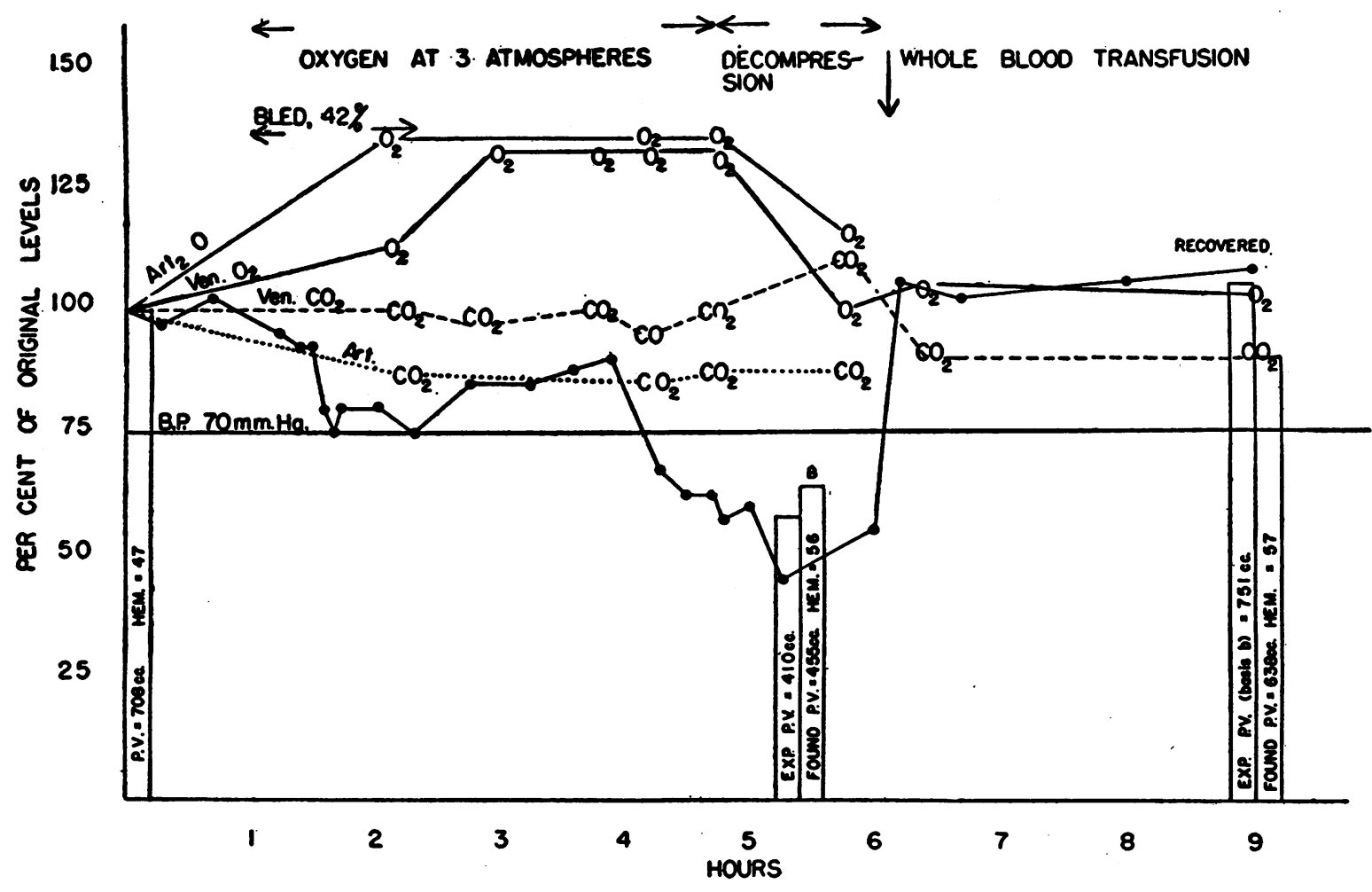

Fig. 5. (Exp. 14.) This dog began to fail while in oxygen and while venous oxygen was above normal. Transfusion caused recovery. Plasma volume did not escape into tissues while in shock phase.

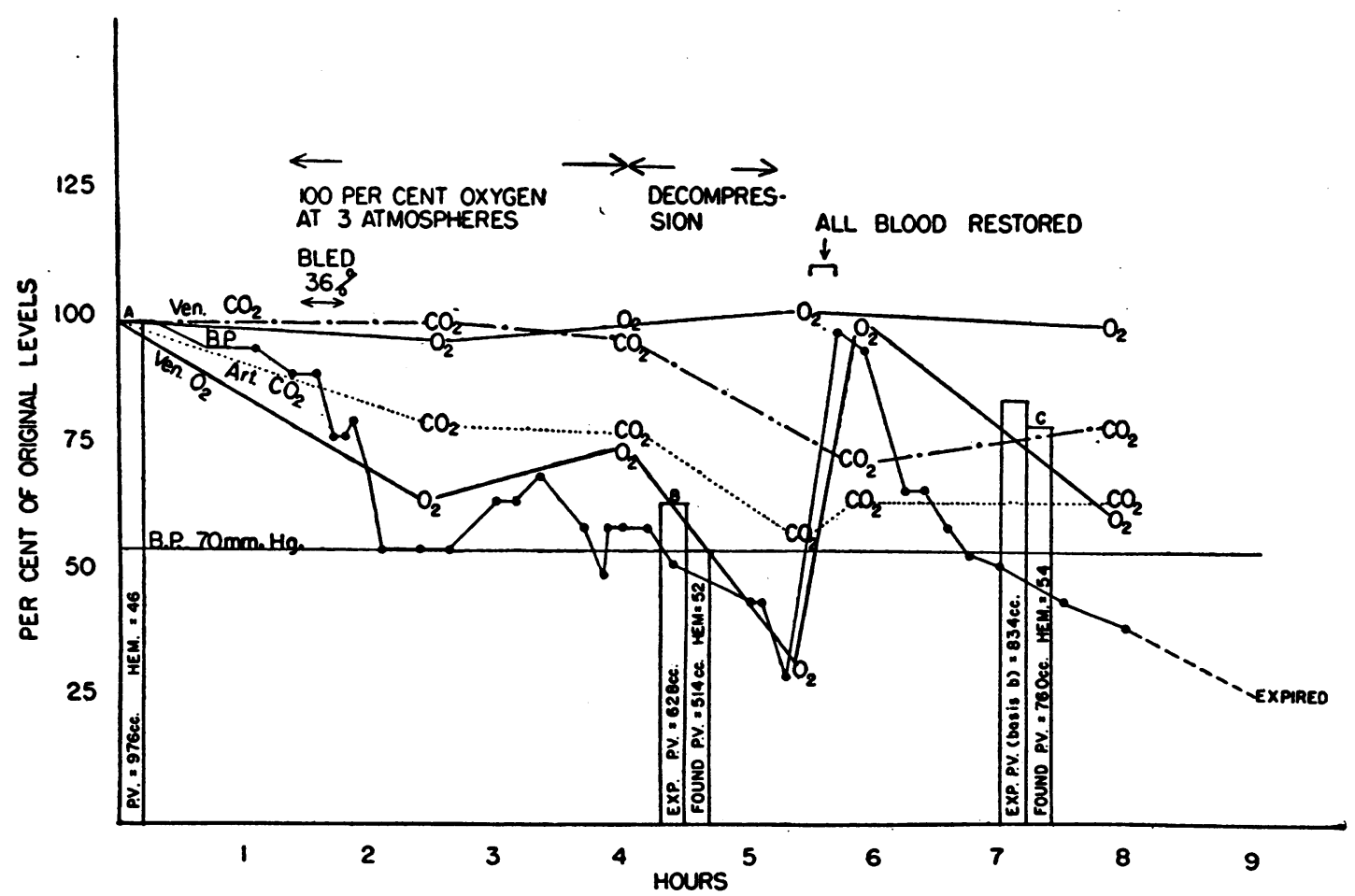

Fig. 6. (Exp. 13.) Venous anoxemia not prevented by oxygen inhalation. Irreversible shock developed in oxygen. Transfusion in irreversible phase corrected anoxemia, but only temporarily. Fatal decline after transfusion not accompanied by fall in plasma volume. 
HOWARD A. FRANK AND JACOB FINE

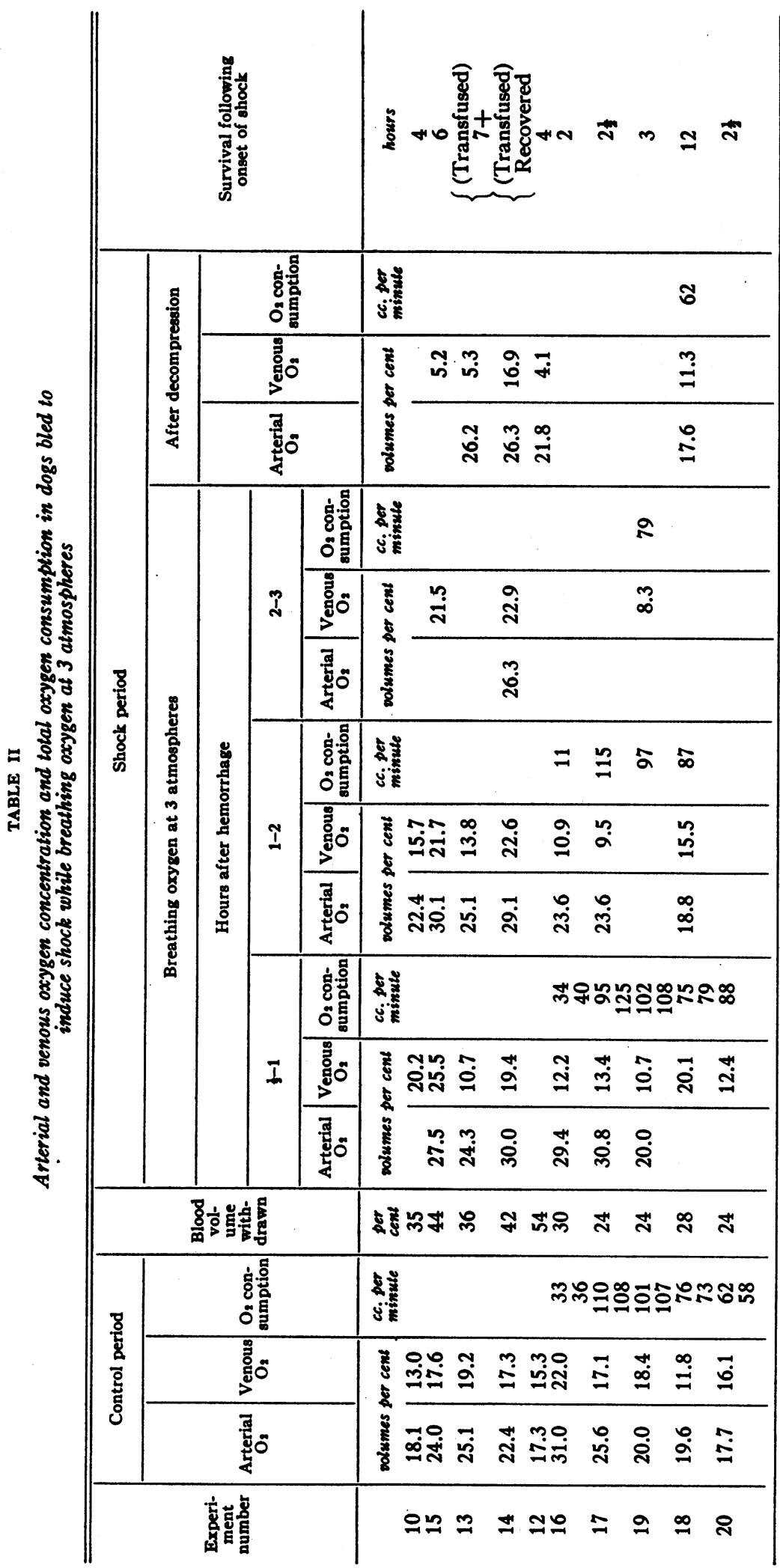


oxygen at three atmospheres had been started. The oxygen was continued for $21 / 2$ to three hours and the train of events observed. The course of circulatory collapse was in no way different from what we and many others have commonly observed when shock is induced by hemorrhage (Figure 4, Table II). The condition of the dog in every case became clearly terminal while oxygen was still being administered. All but one of the dogs in this group died. The surviving animal (Figure 5) recovered after a rapid re-injection of whole blood, equal in volume to that removed. In another dog (Figure 6), a similar procedure failed to produce more than a temporary recovery.

Table II shows that three atmospheres of oxygen given in advance of the onset of shock and continued during shock failed to sustain the venous oxygen concentration in five of ten experiments. In these dogs, collapse and death occurred much earlier (average survival time $32 / 5$ hours) than in the remaining five (average survival time $61 / 2$ hours). One cannot, however, infer a relationship between the speed of the collapse and the ineffectiveness of oxygen inhalation on the venous oxygen concentration, because the survival time of dogs in which the venous oxygen was maintained at normal or above normal levels was no longer than that of dogs in Table $I$ in which the venous oxygen fell, or of other dogs in similar experiments of our own or of others in which no oxygen was given.

Those who have been particularly concerned with the establishment of criteria by which shock induced by hemorrhage may be said to exist, might question the validity of the foregoing experiments on the ground that these dogs may have succumbed to hemorrhage without developing shock. Three experiments (Figures 7, 8, 9) therefore were performed strictly according to the standard of irreversibility in shock from hemorrhage set up by Wiggers and Werle (10), i.e., sufficient bleeding to produce a hypotension of 50 $\mathrm{mm}$. $\mathrm{Hg}$ for 90 minutes and $30 \mathrm{~mm}$. $\mathrm{Hg}$ for an additional 45 minutes, following which blood transfusion, in their experience, uniformly failed to restore the animal. Oxygen at three atmosspheres was started before the bleeding. All three dogs died while still in oxygen, two of them before blood transfusion could be given, and the third despite the return of all withdrawn blood.

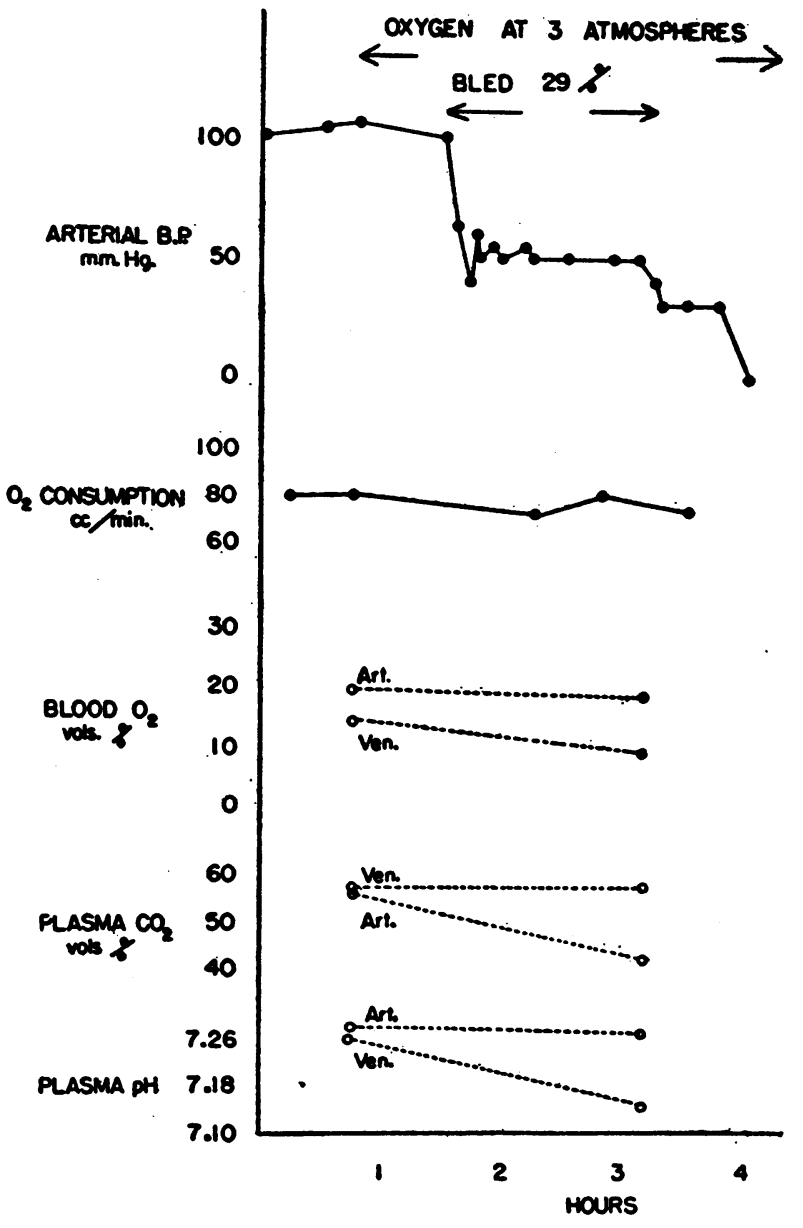

FIG. 7. (Exp. 22.) Death during inhalation of oxygen at three atmospheres despite the restoration of all blood withdrawn. Venous anoxemia not prevented but total oxygen consumption maintained. Increased acidity of venous blood in shock although carbon dioxide content diminished.

The blood pressure, venous and arterial oxygen and carbon dioxide and plasma $\mathrm{pH}$ curves are shown. The data are substantially the same as those of our previous experiments and those of Price et al. (11).

Since pure oxygen, even at three atmospheres, failed to alter favorably any of the commonly observed phenomena in shock, including the survival time, even when the venous oxygen concentration was maintained at normal levels ( 7 of 15 experiments), the likelihood of a beneficial effect from the employment of oxygen at one atmosphere as a therapeutic agent in hemorrhagic shock seems quite remote. 


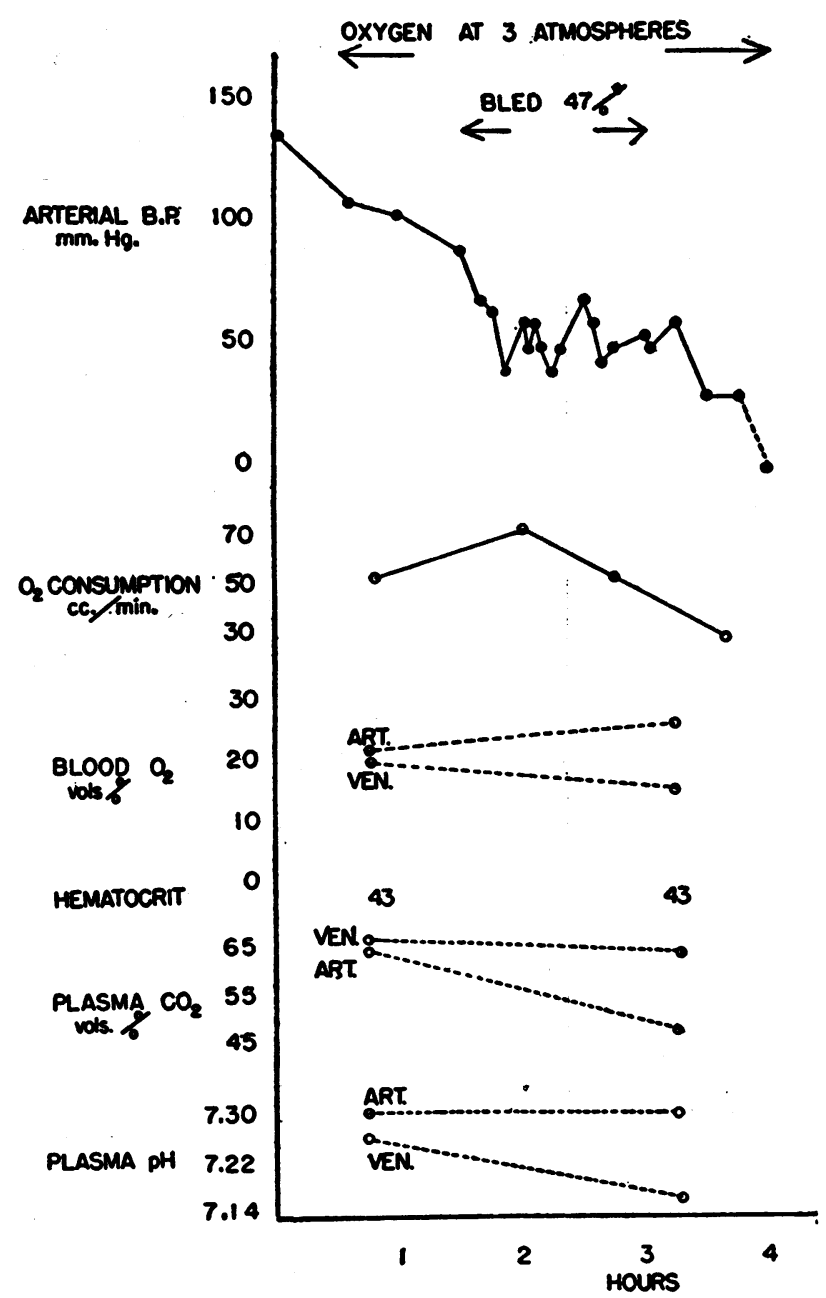

Fig. 8. (Exp. 23.) Death during inhalation of oxygen at three atmospheres. Moderate fall in venous oxygen content but total oxygen consumption not reduced until just before death. Venous blood more acid without change in carbon dioxide content.

Tissue anoxia is presumed to exist in shock because of the low venous oxygen concentration. It is possible, however, that tissue anoxia may continue in spite of the fact that venous oxygen has been restored to normal by the inhalation of oxygen at high pressure, (1) because of actual arterio-venous shunts, or (2) because of the existence of peripheral fields of circulatory failure, whose segregation from active circulation creates what may be regarded in effect as arterio-venous shunts. If tissue anoxia exists, oxygen consumption might fall, providing the tissue requirements have not increased. It is generally assumed that these requirements are decreased, as shown by falling temperature, decreased activity of muscles, decreased urinary excretion, etc. To what extent these decreased requirements are offset by the increased demand of the respiratory muscles is not known. Aub (12) and Blalock (13) found that oxygen consumption did not fall until the late stage of hemorrhagic shock. Gregersen (14) found a substantial decrease in oxygen consumption during traumatic shock. In eight dogs breathing oxygen at three atmospheres, we noted

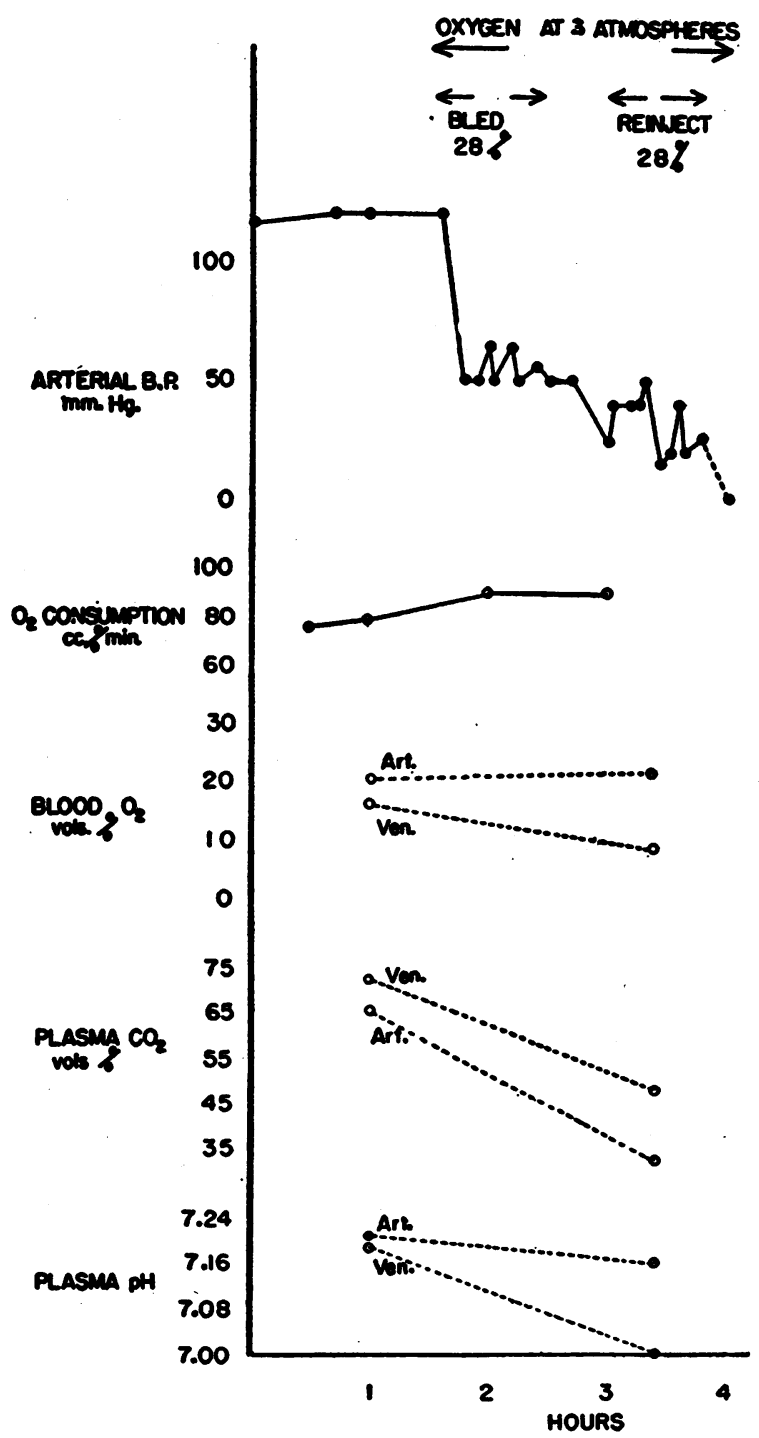

Fig. 9. (Exp. 24.) Death during inhalation of oxygen at three atmospheres. Maintained oxygen consumption and unchanged venous carbon dioxide content. Increased acidity of venous blood. 
TABLE III

Blood oxygen, carbon dioxide content, and total oxygen consumption before and after bleeding, by technique of Wiggers and Werle, to shock in oxygen at 3 atmospheres

\begin{tabular}{|c|c|c|c|c|c|c|c|c|c|c|c|c|}
\hline \multirow{3}{*}{$\begin{array}{c}\text { Experi- } \\
\text { ment } \\
\text { number }\end{array}$} & \multicolumn{5}{|c|}{ Control period } & \multirow{3}{*}{$\begin{array}{c}\text { Blood } \\
\text { volume } \\
\text { with- } \\
\text { drawn }\end{array}$} & \multicolumn{5}{|c|}{ Breathing $\mathrm{O}_{2}$ in 3 atmospheres } & \multirow{3}{*}{$\begin{array}{l}\text { Survival following } \\
\text { onset shock }\end{array}$} \\
\hline & \multicolumn{2}{|c|}{ Arterial } & \multicolumn{2}{|c|}{ Venous } & \multirow{2}{*}{$\begin{array}{l}\mathrm{O}_{2} \text { con- } \\
\text { sumption }\end{array}$} & & \multicolumn{2}{|c|}{ Arterial } & \multicolumn{2}{|c|}{ Venous } & \multirow{2}{*}{$\begin{array}{l}\mathrm{O}_{2} \text { con- } \\
\text { sumption }\end{array}$} & \\
\hline & $\mathrm{O}_{2}$ & $\mathrm{CO}_{2}^{*}$ & $\mathrm{O}_{2}$ & $\mathrm{CO}_{2}^{*}$ & & & $\mathrm{O}_{2}$ & $\mathrm{CO}_{2}^{*}$ & $\mathrm{O}_{2}$ & $\mathrm{CO}_{2}^{*}$ & & \\
\hline & \multicolumn{2}{|c|}{ volumes per cent } & \multicolumn{2}{|c|}{ volumes per cent } & $\begin{array}{l}\text { cc. per } \\
\text { minute }\end{array}$ & per cent & \multicolumn{2}{|c|}{ volumes per cent } & \multicolumn{2}{|c|}{ volumes per cent } & $\begin{array}{l}\text { cc. per } \\
\text { minute }\end{array}$ & hours \\
\hline $\begin{array}{l}22 \\
23 \\
24\end{array}$ & $\begin{array}{l}21.1 \\
18.8 \\
19.0\end{array}$ & $\begin{array}{l}64.4 \\
65.0 \\
58.1\end{array}$ & $\begin{array}{l}18.7 \\
15.8 \\
14.1\end{array}$ & $\begin{array}{l}67.6 \\
72.8 \\
58.3\end{array}$ & $\begin{array}{l}57 \\
75 \\
80\end{array}$ & $\begin{array}{l}28 \\
28 \\
29\end{array}$ & $\begin{array}{l}26.5 \\
20.8 \\
18.0\end{array}$ & $\begin{array}{l}48.0 \\
33.6 \\
42.2\end{array}$ & $\begin{array}{r}14.6 \\
8.6 \\
9.1\end{array}$ & $\begin{array}{l}64.3 \\
48.0 \\
57.1\end{array}$ & $\begin{array}{l}58 \\
91 \\
78\end{array}$ & $2 \frac{21}{4}$ (Transfusion) \\
\hline
\end{tabular}

* Plasma analyses.

an increase in oxygen consumption during hemorrhagic shock until just before death. The increase was presumably due to the marked hyperpnea uniformly observed in such animals.

That the lowered venous oxygen, to some extent at least, is apparently merely an index of a decrease in the velocity of peripheral blood flow, is evident from the fact that temporarily increased velocity of flow in the late shock phase, following intravenous saline solution, causes a rise in venous oxygen. If this inference is correct, the carbon dioxide content of the venous blood should also vary as the velocity of flow. This is, in fact, the case. Studies of the carbon dioxide concentration on arterial and venous bloods in hemorrhagic shock show, as expected, a lowered arterial carbon dioxide concentration due to increased pulmonary ventilation. The venous carbon dioxide remains normal or falls, but in the latter case, not in proportion to the original difference between arterial and venous carbon dioxide. Furthermore, in three experiments following the infusion of saline solution or blood, the venous carbon dioxide content fell still further (Figures 2, 5, 6) although in one experiment, an observation just before death, no substantial change occurred.

The decreasing $\mathrm{pH}$ (Figures 7, 8, 9) and the increasing divergence in the $\mathrm{A}-\mathrm{V}$ difference in $\mathrm{pH}$ as shock proceeds are evidence of an increase in the concentration of non-volatile metabolites. This may in part be due to the mechanisms governing the velocity of peripheral blood flow.

\section{CONCLUSION}

The course of events in hemorrhagic shock is in no way altered when venous anoxemia is pre- vented by administering oxygen at high pressure. Tissue anoxia in these circumstances may still exist, presumably because peripheral stagnation results in what amounts to the existence of an arteriovenous shunt. Oxygen as a therapeutic agent in hemorrhagic shock is therefore of doubtful value.

Further evidence is given that the velocity of peripheral blood flow in hemorrhagic shock is reduced.

Acknowledgment is made to Drs. Arnold M. Seligman, Leroy D. Vandam, and Stanley M. Levenson for assistance in the work in the pressure chamber.

The work described in this paper was done under a contract, recommended by the Committee on Medical Research, between the Office of Scientific Research and Development and Harvard University.

Inclusion of this series of papers in this number of the Journal of Clinical Investigation was made possible by the Josiah Macy, Jr. Foundation, at the request of the editors, in order to provide prompt publication of results of investigation particularly relevant to military medicine.

\section{BIBLIOGRAPHY}

1. Gregersen, M. I., Personal communication.

2. Evans, E. I., Personal communication.

3. Wood, G. O., Mason, M. F., and Blalock, A., Studies on effects of inhalation of high concentration of oxygen in experimental shock. Surgery, 1940, 8, 247.

4. Schnedorf, J. G., and Orr, T. B., Beneficial effects of oxygen therapy in experimental traumatic shock. Surg., Gynec., and Obst., 1941, 73, 79. Oxygen therapy in shock due to hemorrhage. Surg., Gynec., and Obst., 1941, 73, 495.

5. Behnke, A. R., Shaw, L. A., Shilling, C. W., Thomson, R. M., and Messer, A. C., Studies on effects of high oxygen pressure: Effect of high oxygen pressure upon carbon-dioxide and oxygen content, 
acidity, and carbon-dioxide combining power of blood. Am. J. Physiol., 1934, 107, 13.

6. Wiggers, C. J., Present status of shock problem. Physiol. Rev., 1942, 22, 74.

7. Gibson, J. G., and Evelyn, K. A., Clinical studies of blood volume: Adaption of method to photoelectric colorimeter. J. Clin. Invest., 1938, 17, 153.

8. Van Slyke, D. D., and Neill, J. M., Determination of gases in blood and other solutions by vacuum extraction and manometric measurement. J. Biol. Chem., 1924, 61, 523.

9. Hastings, A. B., and Sendroy, J., Studies of acidosis : Colorimetric determination of blood $\mathrm{pH}$ at body temperature without buffer standards. J. Biol. Chem., 1924, 61, 695.
10. Wiggers, C. J., and Werle, J. M., Exploration of method for standardizing hemorrhagic shock. Proc. Soc. Exper. Biol. and Med., 1942, 49, 604.

11. Price, P. B., Hanlon, C. R., Longmire, W. P., and Metcalf, W., Experimental shock: Effects of acute hemorrhage in healthy dogs. Bull. Johns Hopkins Hosp., 1941, 69, 327.

12. Aub, J. C., Studies in experimental traumatic shock. I. Basal metabolism. Am. J. Physiol., 1920-21, 54, 388.

13. Blalock, A., Mechanism and treatment of experimental shock: Shock following hemorrhage. Arch. Surg., 1927, 15, 762.

14. Gregersen, M. I., Personal Communication. 